\title{
Recovery of Critical and Value Metals from Mobile Electronics Enabled by Electrochemical Processing
}

Tedd E. Lister ${ }^{*}$, Peiming Wang ${ }^{\dagger}$ and Andre Anderko ${ }^{\dagger}$

\begin{abstract}
Electrochemistry-based schemes were investigated as a means to recover critical and value metals from scrap mobile electronics. Mobile electronics offer a growing feedstock for replenishing value and critical metals and reducing need to exhaust primary sources. The electrorecycling process generates oxidizing agents at an anode to dissolve metals from the scrap matrix while reducing dissolved metals at the cathode. The process uses a single cell to maximize energy efficiency. E vs pH diagrams and metals dissolution experiments were used to assess effectiveness of various solution chemistries. Following this work, a flow chart was developed where two stages of electrorecycling were proposed: 1) initial dissolution of $\mathrm{Cu}, \mathrm{Sn}, \mathrm{Ag}$ and magnet materials using $\mathrm{Fe}^{+3}$ generated in acidic sulfate and 2) final dissolution of $\mathrm{Pd}$ and $\mathrm{Au}$ using $\mathrm{Cl}_{2}$ generated in an $\mathrm{HCl}$ solution. Experiments were performed using a simulated metal mixture equivalent to 5 cell phones. Both $\mathrm{Cu}$ and $\mathrm{Ag}$ were recovered at $\sim 97 \%$ using $\mathrm{Fe}^{+3}$ while leaving $\mathrm{Au}$ and $\mathrm{Pd}$ intact. Strategy for extraction of rare earth elements (REE) from dissolved streams is discussed as well as future directions in process development.

\section{Introduction}

Mobile electronic devices such as smart phones and tablets are a significant source of valuable metals that should be recycled. Each year over a billion devices are sold world-wide and their average life is short. To some extent, valuable metals are already recycled to specifically recover precious metals such as Au. Metals contained in phones, which can be called value metals, are gold, palladium, silver, copper, cobalt and nickel. Devices contain increasing amounts of rare earth elements (REE) which have been designated critical materials. They are contained in displays, speakers and vibrators within the devices. The US Department of Energy (DOE) considers Nd, Dy, $\mathrm{Eu}, \mathrm{Tb}$ and $\mathrm{Y}$ as REE critical materials (2012). Other REEs such as Ce, La and Pr were deemed near critical. REEs are mined as a group where total REE concentrations in the ore are generally below $8 \%$ (Goonan, 2011). Many of the critical REEs have low abundance in the ore. Thus, when specific elements become critical, significantly more ore must be processed to capture the dilute but valuable critical elements. Targeted recycling of items containing these critical materials could address their future criticality.
\end{abstract}


Reviews of REE reserves, suppliers, applications and potential recycling sources are available (Buchert et al., 2012; Schüler et al., 2012). REEs are contained in mobile electronics, particularly $\mathrm{Nd}$ in magnet materials (Buchert et al., 2012). REEs are used in increasing amounts in green energy technologies such as direct drive windmills and hybrid electric vehicle motors. Many of the devices that utilize large amounts of critical REEs have long service lives and thus are not currently available in significant amounts. Mobile electronics, which have very short useful lifetimes, offer a supply of critical REEs along with other value metals such as $\mathrm{Au}, \mathrm{Pd}, \mathrm{Ag}, \mathrm{Co}$ and $\mathrm{Cu}$.

Technology-rich devices such as smart phones and tablets continue to grow in use (CCS Insight, 2013). Mobile electronics recycling presents an enormous resource of critical and value metals. World sales for mobile phones (cell and smart phones) were approximately 1.7 billion in 2011 and 2012 (Gartner, 2013). The average device has a lifetime of 18 months in the United States (Environmental Protection Agency, 2004). Worldwide tablet sales for 2013 are estimated to be over 182 million, growing from 112 million in 2012 (Gartner, 2012). By the end of 2013 there will be 5.9 billion mobile devices in use (CCS Insight, 2013). Worldwide combined sales of smart phones and tablets are expected to reach 2.1 billion in 2017.

As mobile electronics have evolved, the size of circuitry has decreased as discrete components (processors, displays, speakers, cameras, microphones, etc.) are employed in lesser amounts. Unlike personal computers (PC), component by component (display, speakers, hard drive, etc.) separation for targeted recycling processes are less favorable due to small amounts of material involved. Value metals within mobile electronics are contained within circuitry and peripheral components such as displays and speakers. $\mathrm{Cu}$ is used to connect circuit elements. Solder is used to form permanent electrical connections. Pb-free solder is used to meet the Reduction of Hazardous Substances (ROHS) directive and contains Sn-Ag or Sn-Ag-Cu alloys. Surface contacts for non-permanent connections are coated with Au which may be deposited on interlayers such as Ni. Surface mount Ta capacitors utilize Ag and Pd in electrodes. High strength Nd-Fe-B magnets are used for speakers and vibrators (Buchert et al., 2012). Display backlighting in mobile devices use light emitting diode (LED) sources which contain small amounts of REE phosphors including Eu, Y and Tb (Buchert et al., 2012). The Li-ion batteries used to power devices contain significant amounts of valuable Co. In 2006, the USGS assessed the metals content of mobile phones (Sullivan, 2006). At that time a metals recycler estimated that 1 ton of cell phones contained $140 \mathrm{~kg}$ $\mathrm{Cu}, 3.14 \mathrm{~kg} \mathrm{Ag}, 300 \mathrm{~g} \mathrm{Au}, 130 \mathrm{~g} \mathrm{Pd}$ and $3 \mathrm{~g} \mathrm{Pt}$. Precious metals comprise the greatest value ( $91 \%)$ of recoverable metals (Hageluken, 2006). Mobile electronics (smart phones and tablets) pack more technology into a similar package and are likely to contain higher metal content per unit (Buchert et al., 2012). Thus, significant amount of critical, near critical and value metals are present with these devices and provide opportunity for economic and environmentally sound recovery methods.

Significant work has been reported on the recovery of metals from electronics printed circuit boards (PCB) (Hageluken, 2006; Cui and Zhang, 2008; Huang et al., 2009; Tuncuk et al., 2012). 
These methods are analogous to those in mining operations where metals can be in higher concentration than in ore bodies (Huang et al., 2009). The dissolution of PCB metals has largely been performed using one of three acids: $\mathrm{HCl}, \mathrm{H}_{2} \mathrm{SO}_{4}$ and $\mathrm{HNO}_{3}$. The choice of acid is generally a balance of dissolution speed and compatibility with downstream processing of the leachate solution. Both $\mathrm{HCl}$ and $\mathrm{H}_{2} \mathrm{SO}_{4}$ rely on dissolved $\mathrm{O}_{2}$ as an oxidizing agent while $\mathrm{HNO}_{3}$ is itself an oxidizer. Oxidizers, such as $\mathrm{Cl}_{2}, \mathrm{H}_{2} \mathrm{O}_{2}$ and $\mathrm{Fe}^{+3}$, can be added to enhance dissolution rates (Tuncuk et al., 2012). Cu dissolution using $\mathrm{FeCl}_{3}$ has been demonstrated (Wang et al., 2010b). In situ generated $\mathrm{Cl}_{2}$ from mixing bleach and $\mathrm{HCl}$ is a powerful oxidizer (Herraros et al., 1999). For dissolution of precious metals aqua regia $\left(\mathrm{HCl}-\mathrm{HNO}_{3}\right)$ is costly but effective, where $\mathrm{NO}_{3}{ }^{-}$or nascent $\mathrm{Cl}_{2}$ acts as the oxidizer and $\mathrm{Cl}^{-}$forms stable ion complexes (Huang et al., 2009). Complexing agents can be used to stabilize solution species and reduce the required oxidizing strength. Cyanide is common in mining (Huang et al., 2009) but is considered an environmental hazard. Molecular $\mathrm{Cl}, \mathrm{Br}$ and I are well suited to dissolution of gold, acting as both the oxidizer and complexing agent. The order of stability for Au complexes increases going down the periodic chart from $\mathrm{Cl}$ to $\mathrm{I} . \mathrm{Cl}_{2}$ is manufactured by the electrochemical chlor-alkali process, providing a controlled means for on-site generation. Ag forms insoluble compounds with the halides, complicating the use of single step processes to dissolve all value metals.

Electrochemistry-based metal recovery schemes have been described for various metal recovery applications. Two functions have been described: 1) anodic generation of oxidizers to speed dissolution of metals from scrap or 2) cathodic electrowinning of leached metals for separation and recovery. Given proper consideration, the two processes may the performed in a single cell.

Electrowinning of metals is commonly reported where dissolved metal ions are electroreduced to capture and separate from the leach solution. Due to upstream chemistry unique to recycling, chemistry might be less than ideal compared with optimized electroplating or electrorefining chemistries. Electrowinning requires the reduction potential of the metal to be similar or more positive than the water reduction potential or primarily $\mathrm{H}_{2}$ is produced. Several processes have been reported which use electrowinning to capture $\mathrm{Cu}$ or $\mathrm{Ni}$ from leachate solution (Oishi et al., 2007; Mecucci and Scott, 2002; Viet et al., 2006; Masavetas et al., 2009). While electrowinning may be performed for many transition metals it is not possible to reduce REEs to metal from aqueous solutions. A mixed metal solution will also complicate the electroreduction process where more noble metals may prevent polarization to capture less noble ones. This can be used to electrorefine metals and thus enable separation.

Electrochemical processes have been developed to create a chemical environment to dissolve metals. Proton generation at the anode during oxidation of water to $\mathrm{O}_{2}$ can sustain low $\mathrm{pH}$ environments to enable dissolution. In situ generation of $\mathrm{Cl}_{2}$ in $\mathrm{HCl}$ electrolytes has been reported for dissolving $\mathrm{Cu}$ in PCBs (Kim et al., 2008; Kim et al., 2010; Kim et al., 2011). This work used an anion exchange membrane (AEM) separated cell with a graphite anode. Leaching was performed 
at room temperature due to the limited solubility of $\mathrm{Cl}_{2}$ gas at elevated temperatures. Leaching of $\mathrm{Pb}, \mathrm{Sn}, \mathrm{Zn}$ from PCB material approached $100 \%$ with $\mathrm{Cu}$ being somewhat lower attributed to $\mathrm{CuCl}$ passivation (Kim et al., 2011). Ping et al. noted a significant increase in dissolution rate using electrogenerated $\mathrm{Cl}_{2}$ versus dissolved $\mathrm{O}_{2}$ from air as used for typical leaching (Ping et al., 2011).

Processes have also been described which perform both dissolution and electrowinning functions in the same cell, thus providing high electron efficiency. A system based on $\mathrm{Cl}^{-}$ electrolytes was described, where $\mathrm{Cl}_{2}$ was electrogenerated and fed to a dissolution vessel while dissolved metals were electrowon as a group at the cathode (Diaz et al., 1993; Brandon et al., 2001; Cheng et al.). Analogous schemes have also been investigated for mining applications. Copper matte was electrorefined by generating $\mathrm{Fe}^{+3}$ at the anode to dissolve $\mathrm{Cu}$ and electrowin at the cathode (Jiricny et al., 2002a; Jiricny et al., 2002b). These dissolution processes are analogous to electroplating methods utilizing a dissolving anode except the oxidizer/mediator acts as an electron shuttle in place of direct contact. This allows a complex partially conductive matrix, such as shredded electronic scrap, to be processed and separated in a single cell.

Recycling methods for REEs are not as well developed compared to value metals but are becoming of interest due to global demand. Reviews have recently outlined potential REE recycling feedstocks, existing recycling technologies and future needs (Binnemans et al., 2013; Tanaka et al., 2013; Anand et al., 2011). Projections suggest that particular REEs such as Dy will see increasing demand (Alonso et al., 2012; Hoenderdaal et al., 2013). Nd-Fe-B magnet alloys dissolve rapidly in acid solutions and are typically coated with $\mathrm{Ni}$ or layers of $\mathrm{Ni}$ and $\mathrm{Cu}$ for protection. Selection of the dissolution chemistry depends on the anticipated recovery process. REEs form insoluble trihydroxides species in basic medium (Pourbaix, 1974). This can be used to precipitate the REEs but requires a significant $\mathrm{pH}$ shift for acid-based leaching chemistries. The $\mathrm{pH}$ shift is also higher than for commonly dissolved metals such as Fe and Ni. REEs are very soluble in chloride and nitrate while having low solubility in sulfate except at low pH (Stevenson and Nervik, 1961). From moderate $\mathrm{H}_{2} \mathrm{SO}_{4}$, a slight increase in $\mathrm{pH}$ to slightly over 1 will precipitate the REEs as double salts $\left((\mathrm{REE})_{2}\left(\mathrm{SO}_{4}\right)_{3} \cdot \mathrm{Na}_{2} \mathrm{SO}_{4} \cdot \mathrm{xH}_{2} \mathrm{O}\right.$ using $\left.\mathrm{NaOH}\right)$. This was used to capture REE from Ni-MH batteries (Pietrelli et al., 2002; Bertuol et al., 2009). Pietrelli described leaching with $2 \mathrm{M} \mathrm{H}_{2} \mathrm{SO}_{4}$ resulting in over $90 \%$ REE release then increased $\mathrm{pH}$ to 1.5 with $\mathrm{NaOH}$ to recover over $70 \%$ of REE content (2002). REEs were recovered from magnet scrap (swarf) using sulfuric acid to dissolve followed by $\mathrm{NaOH}$ addition to form double salt precipitate (Lyman and Palmer, 1995). Phosphoric acid dissolution followed by $\mathrm{pH}$ increase has been used to precipitate REEs from $\mathrm{HCl}$ leached $\mathrm{Ni}-\mathrm{MH}$ battery material (Lyman and Palmer, 1995). Lamp phosphors show a wide variation in ease of dissolution (Binnemans et al., 2013). Specific recycling of REE from LEDs used for display backlighting was not found. Solvent extraction (SX) methods are commercially used to extract and separate dissolved REEs. SX has been used to recover dissolved REEs from Ni-MH batteries. Tzanetakis dissolved Ni-MH batteries in $\mathrm{HCl}$ and used $25 \%$ bis-(2-ethylhexyl) phosphoric acid) (D2EHPA) in kerosene (Tzanetakis and Scott, 2004). Extraction at pH 2.5 removed nearly 100\% 
REEs, however, other metals were also extracted. Nuclear applications have extensively used SX for removing REE fission products for fuel reprocessing (Stevenson and Nervik, 1961).

Electrochemistry offers unique methods of enabling recovery of critical and value metals from mobile devices while minimizing chemical usage. Previous work has demonstrated processes using chlorine based solution to dissolve metals in a single chemistry (Kim et al., 2008; Kim et al., 2010; Kim et al., 2011). Other work has included dissolution and recovery using similar chemistry (Diaz et al., 1993; Brandon et al., 2001; Cheng et al.). This paper describes use of both mild and strong oxidizers to develop electrochemical processes for mobile electronics. The processes described below utilizes oxidizers formed at the anode to enable dissolution of metals while electrowinning the dissolved metals at the cathode. Analysis and experiments will be presented below in the development of a process which aims to reduce chemical consumption while effectively recovering critical and value metals.

\section{Experimental}

\subsection{Materials and chemicals}

Experiments were performed using pure metal, alloys or fine shot as surrogates for metals in recycled material. Pure foils of $\mathrm{Sn}, \mathrm{Ni}, \mathrm{Cu}, \mathrm{Ag}, \mathrm{Au}$ and $\mathrm{Pd}$ were employed in corrosion experiments. These metals were of varied purity level and thickness. Solder was obtained from a spool of Kester $\mathrm{Pb}$ free solder with $98 \% \mathrm{Sn}$ and $2 \% \mathrm{Ag}$ as supplied by manufacturer. Magnets were obtained from a commercial supplier (K\&J Magnetics) which were either Grade N42 disks (1/4" x 1/16") coated with Ni-Cu-Ni triple plate or Grade N52 disks (1/4" x 1/8") with a black epoxy coating. The epoxy coating was removed by abrasion prior to testing. Solutions were made using ACS grade or better chemicals. Solutions were made using water purified from a Barnstead Nanopure Diamond filtration system with a resistivity of 18.2 Mohms-cm.

\subsection{Thermodynamic data and calculations}

To elucidate the conditions that lead to the electrochemical dissolution of metals and the formation of metal oxides/hydroxides, thermodynamic calculations have been performed using the Mixed-Solvent Electrolyte (MSE) thermodynamic model of Wang et al. (2002; 2006). This model is particularly suitable for reproducing the solubility of various salts and oxides in multicomponent solutions, including both dilute and concentrated acid environments (Wang et al., 2010a). Parameters of the MSE model were regressed using experimental data for multiple properties (i.e., solid-liquid equilibria, vapor-liquid equilibria, osmotic and activity coefficients, heats of mixing and dilution, and heat capacities) as described in previous studies (Wang et al., 2002; Wang et al., 2006). The obtained parameters have been incorporated into the Corrosion Analyzer software (Corrosion Analyzer version 9.1.3, OLI Systems, Inc.), which has been used to make the calculations reported here.

Using the MSE model, E-pH (or Pourbaix) electrochemical diagrams were generated using the algorithm of Anderko et al. (1997) as implemented in the Corrosion Analyzer software. This 
algorithm makes it possible to incorporate the effects of complexation and solution nonideality into the calculation of boundary lines between the stability fields of various species. For applications in which redox equilibria do not play a role (e.g., precipitation of oxides by varying $\mathrm{pH}$ ), the phase behavior was visualized using a different kind of diagrams, referred to as chemical diagrams (Lencka et al., 1997). Such diagrams depict the stability areas of solid phases and aqueous species as a function of $\mathrm{pH}$ and the overall concentration of metals.

\subsection{Corrosion rate measurements}

Corrosion rates for pure metals and alloys were determined using weight loss when exposing pure thin foils. This data was acquired as a starting point for assessing dissolution chemistries. Solution compositions were values anticipated from preliminary proof-of-concept experiments not presented here. Experiments were performed with the corrosion vessel placed in a water bath at 60 $\pm 2^{\circ} \mathrm{C}$. Experiments which did not employ electrogenerated $\mathrm{I}_{2}$ or $\mathrm{Cl}_{2}$ used $25 \mathrm{~mL}$ of solution which was mixed with a stir bar or if magnetic (Ni or magnets) using the specimen itself. $\mathrm{Cl}_{2}$ was generated using a separate electrolysis cell from $\mathrm{NaCl}$ electrolyte where the headspace was bubbled into $5 \mathrm{~mL}$ of solution. A similar cell was used to generate $\mathrm{I}_{2}\left(\mathrm{or}_{3}{ }^{-}\right.$) from a $0.5 \mathrm{M} \mathrm{Nal}$ solution which was continuously pumped from the electrolysis cell to the reaction solution $(\sim 25 \mathrm{~mL})$ in a water bath. During exposure $\mathrm{I}_{2}$ exceeded solubility as evidenced by solid $\mathrm{I}_{2}$ present. For all experiments the exposure time varied depending on the expected reaction rate such that reactant was not depleted during the experiment. Weight of each specimen was recorded three times before and after experiments using a 5 place balance $( \pm 0.00005 \mathrm{~g}$ accuracy). The estimated surface area, exposure time, density and weight loss were used to calculate the corrosion rate in $\mu \mathrm{m} / \mathrm{hr}$. The corrosion rate assumes uniform loss of material from the specimen which is considered valid due to the rates observed and lack of significant pitting observed.

\subsection{Electro-recycling system}

A diagram of the electrorecycling system is shown in Figure 1. The electrochemical cell used a trough configuration which also held the cathode solution. The cathode, which consisted of $9 \mathrm{~cm}$ by $10 \mathrm{~cm} \mathrm{Cu}$ foil, was suspended into the bulk of the solution for ease of replacement as product growth occurs. Cathodes were cut from $0.127 \mathrm{~mm}$ thick Cu foil (Aldrich 99+\%). The submerged area was approximately $9 \mathrm{~cm} \times 8 \mathrm{~cm}$. One end of the cell held the anode compartment. A dimensionally stable anode (DSA) coating formed on Grade 2 titanium sheet was employed as an anode. The DSA coating was applied to both sides by brushing $\mathrm{H}_{2} \mid \mathrm{rO}_{3}$ diluted in isopropyl alcohol onto the exposed surfaces followed by heating at $550^{\circ} \mathrm{C}$ for 2 hours to form $\mathrm{IrO}_{2}$. The DSA had an array of $3 / 32$ " holes spaced $1 / 8$ " apart to allow solution passage through to the cell exit. The anode and cathode solutions were separated by two layers of PTFE mesh. Solution was pumped (5-10 $\mathrm{mL} / \mathrm{min}$ ) through the anode compartment where oxidizer was generated to the dissolver which through gravity returns to the dissolver tank. The dissolver was a Buchner filter funnel (Chemglass) which contained simulated metals content for recovery. A custom lid was machined to allow solution 
to drip through four symmetric holes onto the metal and position the thermocouple near the center of the dissolver. Heating tape was applied to the dissolver walls to increase solution temperature to promote increased corrosion rates. Temperature was maintained at $60^{\circ} \mathrm{C}$ in the dissolver using a temperature controller. A DC power supply was used to polarize the cell using a constant current. A redox probe was inserted between the cell exit and the dissolver to track the state of the oxidizer. The cell voltage $\left(E_{\text {cell }}\right)$ and redox potential $\left(E_{\text {red }}\right)$ was collected manually.

\subsection{Analysis}

Solutions from electrorecycling experiments were analyzed for dissolved metal ions content using an inductively coupled plasma mass spectrometer (ICP-MS). Calibration was performed using commercially prepared standards (VGH and Spex). Composition of magnet and solder alloys was determined by complete dissolution and subsequent ICP-MS analysis of the solution. Table 1 shows a table of the metals composition for these alloys. Cathodes were chemically analyzed by either sectioning portions or removing friable dendrites and dissolving in concentrated $\mathrm{HNO}_{3}$. Copper surfaces were analyzed by scanning electron microscopy (SEM) and energy dispersive spectroscopy (EDS) using a Quanta FEG 650.

\section{Results and Discussion}

\subsection{Thermodynamic and solubility data}

As part of the initial process development, a thermodynamic analysis was performed using common oxidizers that can be electrochemically cycled. The oxidizers chosen were $\mathrm{Fe}^{+3}, \mathrm{Cl}_{2}, \mathrm{Br}_{2}$ and $\mathrm{I}_{2}$. Other possibilities include $\mathrm{Ce}^{+4}, \mathrm{O}_{2}$ and $\mathrm{O}_{3}$ but were considered either too positive $\left(\mathrm{Ce}^{+4}\right)$, difficult/inefficient to generate $\left(\mathrm{O}_{3}\right)$ or and available naturally $\left(\mathrm{O}_{2}\right)$. The metals considered in the analysis were those found in electronics in order of nobility: $\mathrm{Fe}, \mathrm{Ni}, \mathrm{Sn}, \mathrm{Cu}, \mathrm{Ag}, \mathrm{Pd}$ and $\mathrm{Au}$. E vs. pH diagrams were generated to evaluate metal dissolution by the various oxidizers. Although diagrams for other solution/metal compositions were examined, the diagrams presented below focus on the chemistry developed in this paper at $60^{\circ} \mathrm{C}$. Figure 2 shows $\mathrm{Sn}, \mathrm{Cu}$, and $\mathrm{Ag}$ overlapping with $\mathrm{Fe}$ in sulfate. As can be seen, $\mathrm{Fe}^{+3}$ region is well positive of these metals with exception of $\mathrm{Ag}$, where stability ranges overlap. This analysis suggests that the less noble value metals ( $\mathrm{Sn}, \mathrm{Cu}$ ) should dissolve while Ag required additional experimental study. Noble metals (Au and Pd) were not evaluated with sulfate due to their high reduction potentials and lack of complexation. Figure 3 shows $\mathrm{Pd}$ and $\mathrm{Au}$ metals with $\mathrm{Cl}$ present. Both metals form stable complexes at low potentials. Although not shown, $\mathrm{Br}$ and I form complexes at even lower potentials. Au can be readily dissolved in neutral I while Pd appears to form insoluble surface films in I as will be discussed below. Thus for dissolution of $\mathrm{Au}$ and $\mathrm{Pd}$, halides provide ample dissolution strength combined with formation of stable ions.

REEs dissolved in sulfuric acid can be precipitated by addition of base to increase pH slightly. Figure 4 shows the solubility of $\mathrm{Nd}$ species in $1 \mathrm{M} \mathrm{H}_{2} \mathrm{SO}_{4}$ where $\mathrm{pH}$ is adjusted using $\mathrm{NaOH}$. The solubility of the sulfate complex decreases with $\mathrm{pH}$ until about $\mathrm{pH} 1.8$, then levels off until hydroxide 
precipitation around $\mathrm{pH} 7$. Note that the precipitation of the double salt is sensitive to initial acid strength.

Due to the complex mixture of dissolved ions anticipated, sensitivity to redox chemistry was probed by mixing dissolved species. In particular, $\mathrm{Cu}$ and $\mathrm{Sn}$ have high composition in mobile electronics. Figure 5 predicts the speciation after mixing $\mathrm{CuSO}_{4}$ and $\mathrm{SnSO}_{4}$ as a function of $\mathrm{H}_{2} \mathrm{SO}_{4}$ concentration. $\mathrm{Cu}(\mathrm{s})$ and $\mathrm{SnO}_{2}$ are thermodynamically favored and thus precipitate formation is anticipated. More details about this reaction will be discussed below.

\subsection{Corrosion of pure metals}

To assess solution chemistry and develop a recycling scheme, experiments were performed using pure metals and/or alloys for elements and alloys of interest. This data, taken in parallel, supplements the thermodynamic data described above. Table 1 provides the corrosion rates determined through the corrosion tests. Corrosion data was primarily collected in $1 \mathrm{M} \mathrm{H}_{2} \mathrm{SO}_{4}$ and 2 $\mathrm{M} \mathrm{HCl}$ to assess base case with $\mathrm{O}_{2}$ as the oxidizer. To ensure $\mathrm{O}_{2}$ concentration, ambient air was bubbled into the solution during exposure. Other tests investigated oxidizers which can be electrogenerated $\left(\mathrm{Fe}^{+3}, \mathrm{Cl}_{2}\right.$ and $\left.\mathrm{I}_{2}\right)$ in acid sulfate and chloride solutions. Some combinations were not examined due to known solubility issues. For example, Ag forms insoluble halide species while Pd halide complexes are insoluble except in acidic solutions.

Dissolution rates for all pure metals in acids with only dissolved $\mathrm{O}_{2}$ were all below $1 \mu \mathrm{m} / \mathrm{hr}$ with the exception of $\mathrm{Sn}$ in $\mathrm{HCl}$. In comparison, rates in the presence of $\mathrm{Fe}^{+3}$ show significant acceleration for $\mathrm{Ni}, \mathrm{Sn}, \mathrm{Cu}$ and $\mathrm{Ag}$. Dissolution rates were not particularly sensitive to chloride or sulfate salts. To test the sensitivity of $\mathrm{Ag}$ dissolution to $\mathrm{Fe}^{+3}$ concentration, a specimen exposed to $10 \mathrm{mM} \mathrm{Fe}^{+3}$ in $1 \mathrm{M} \mathrm{H}_{2} \mathrm{SO}_{4}$ had a dissolution rate of $5.1 \mu \mathrm{m} / \mathrm{hr}$ which is only a modest decrease in rate. The effect of $\mathrm{Cu}^{+2}$ was also evaluated to determine if $\mathrm{Cu}^{+2}$ accelerates less noble metal dissolution. As $\mathrm{Cu}$ is a primary metal in electronic circuitry, a significant concentration will be present in solution. There is a significant effect for $\mathrm{Cu}^{+2}$ on $\mathrm{Sn}$ and solder but a lesser effect for $\mathrm{Cu}$ itself.

Many solutions with dissolved Sn produced precipitates days after the experiment was complete. For Sn containing materials dissolved in $\mathrm{Cu}^{+2}$, two precipitates were formed: a fine white precipitate and $\mathrm{Cu}$ metal. The white precipitate is likely insoluble $\mathrm{SnO}_{2}$ while the metallic $\mathrm{Cu}$ is likely from a redox reaction with $\mathrm{Sn}$. This agrees with the thermodynamic data shown in Figure 5 where the mixture of $\mathrm{SnSO}_{4}$ and $\mathrm{CuSO}_{4}$ is predicted to form $\mathrm{SnO}_{2}$ and $\mathrm{Cu}$ metal. Eventually, the $\mathrm{CuSO}_{4}$ color from aging solution is reduced. In sulfate solutions without $\mathrm{CuSO}_{4}$ white precipitates were observed after several days indicating $\mathrm{SnO}_{2}$ formation in reaction with $\mathrm{O}_{2}$. No precipitates were observed in $\mathrm{Sn}$ dissolved in $\mathrm{HCl}$ solutions. This could be due to the reducing nature of $\mathrm{HCl}$.

Experiments in $\mathrm{HCl}$ with $\mathrm{Cl}_{2}$ dissolved $\mathrm{Pd}$ and $\mathrm{Au}$ efficiently. It was found that $\mathrm{Au}$ could dissolve in pure water saturated with $\mathrm{Cl}_{2}(1.94 \mu \mathrm{m} / \mathrm{hr})$. However, $\mathrm{Pd}$ required acidic conditions to dissolve. The rates for less noble metals were in most cases lower than observed for $\mathrm{Fe}^{+3}$. For $\mathrm{I}_{2}$ in $\mathrm{Nal}, \mathrm{Au}$ 
could be dissolved more rapidly than in $\mathrm{Cl}_{2}$. However, $\mathrm{Pd}$ did not dissolve in neutral $\mathrm{I}_{2}$ as observed for $\mathrm{Cl}_{2}$. This was attributed to the formation of an insoluble $\mathrm{Pdl}_{2}$ film evidenced by a dark film on the Pd surface after exposure. It was decided that $\mathrm{HI}$ would be prohibitively expensive to pursue and thus not tried. Thus to dissolve both $\mathrm{Au}$ and $\mathrm{Pd}$, a solution with $\mathrm{Cl}_{2}$ in $2 \mathrm{M} \mathrm{HCl}$ appears to be the best choice of those tested.

Two alloys of interest to recycling efforts are the $\mathrm{Nd}-\mathrm{Fe}-\mathrm{B}$ magnets and $\mathrm{Pb}$-free solder. Uncoated Nd-Fe-B magnets rapidly dissolved in acid solutions with profuse $\mathrm{H}_{2}$ bubble evolution. Metal coated magnets could be dissolved in $\mathrm{Fe}^{+3}$ where the corrosion rate was lower due to the initial time required to break through the $\mathrm{Ni}-\mathrm{Cu}-\mathrm{Ni}$ coating. After the initial delay, rapid dissolution as observed for the uncoated magnet occurred. The magnet would dissolve leaving a partial shell of the more resistant coating. $\mathrm{Pb}$-free solder, containing $\mathrm{Sn}$ and $\mathrm{Ag}$ rapidly dissolved in $2 \mathrm{M} \mathrm{HCl}$. Rapid dissolution was also observed in $\mathrm{CuSO}_{4}$ as observed for pure $\mathrm{Sn}$. A two part precipitate formed in the solution days after the experiment as described for $\mathrm{Sn}$ in $\mathrm{CuSO}_{4}$.

\subsection{Development of flow sheets}

The thermodynamic and corrosion data were used to develop possible flow sheets for electrorecycling of the metals in mobile electronics. The flow sheets were developed with an attempt to simplify the number of pre-processing steps in order to use the electrochemical process to remove the metals from the material and provide material for further separation and processing into pure materials. Electrorecycling will excel at dissolution of the metals and recovery of some metals at the cathode. Other processes will be required to complete recovery. As shown above, the oxidizer strength greatly influences which metals are dissolved. This can be used to perform a two stage dissolution shown in Figure 6 . The first stage uses electrogenerated $\mathrm{Fe}^{+3}$ in acidic sulfate media to dissolve $\mathrm{Fe}, \mathrm{Ni}, \mathrm{Sn}, \mathrm{Cu}, \mathrm{Ag}$ and REEs. The most noble of these will be preferentially reduced at the cathode: Ag and Cu. Cu deposition is well established in acidic sulfate solutions (Dini, 2000). The REEs are captured by either precipitation as sulfate double salts or through solvent or membrane extraction. This could be part of the process or performed periodically after accumulation of REEs. Loss of $\mathrm{H}^{+}$can be alleviated through operation of the system at increased current such that water oxidation accompanies $\mathrm{Fe}^{+3}$ generation thus generating $\mathrm{H}^{+}$. After most of these metals are dissolved and captured, an $\mathrm{HCl}$ solution can be introduced where $\mathrm{Cl}_{2}$ is electrogenerated at the anode to dissolve $\mathrm{Au}$ and $\mathrm{Pd}$. An alternative approach would be to use a single $\mathrm{HCl}$ based solution $\left(\mathrm{Cl}_{2}\right.$ oxidizer) to dissolve most of the metals. This approach introduces the likelihood of enhanced $\mathrm{Cu}$ dendrite formation at the cathode due to influence of $\mathrm{Cl}$ (Shao et al, 2009). Thus a cell which can mechanically control dendrite formation may be needed. Such a cell would mechanically remove dendrites and collect them in a basket under the electrode for retrieval. Alternatively deposits could be stripped periodically as performed in electrorefining (Beukes and Badenhorst, 2009). The other important issue with this approach is that $\mathrm{Ag}$ will form $\mathrm{AgCl}$ and will need to be stripped from the remaining waste afterwards. In lieu of a second electrorecycling stage in $\mathrm{HCl}$, a 
purely chemical dissolution stage on the remaining Au and Pd which is about 2 orders of magnitude smaller in content than $\mathrm{Cu}$.

\subsection{Electro-recycling experiments on simulated electronic materials}

The electrorecycling system was presented earlier in Figure 1. In developing the electrorecyling system, several design iterations were investigated. Two prime goals of a system are to 1) maximize delivery of oxidizer to the metal while minimizing oxidizer reduction at the cathode and 2) deliver dissolved metal ions to the cathode at a rate that enables efficient deposition. The initial iterations used available $\mathrm{H}$-cells and other glassware to test the concept. The initial fabricated system used a conventional sealed flow cell with separate solution reservoir and dissolver. This design, while successful in delivering solutions to the electrodes and dissolver, was inconvenient due to difficulty in removing the cathode. The next design incorporated the reservoir into the cell (trough design) where the cathode could be removed and replaced easily. The anode compartment was located at one end of the trough and solution was pulled through a perforated anode to the dissolver where gravity drained the solution through the scrap and back to the reservoir. While the electrodes resided in the same reservoir, the flow through the cell should limit backstreaming of oxidizer to the cathode.

The electrorecycling system was operated using a mixture of $\mathrm{Cu}, \mathrm{Ag}, \mathrm{Au}, \mathrm{Pd}$ and $\mathrm{Nd}-\mathrm{Fe}-\mathrm{B}$ magnets using published values for the content of cell phones. The mixture was based on 5 cell phones of metal: $80.003 \mathrm{~g} \mathrm{Cu}$ shot, $1.526 \mathrm{~g} \mathrm{Ag}$ foil, $0.0533 \mathrm{~g} \mathrm{Pd}$ foil, $0.1511 \mathrm{~g} \mathrm{Au}$ foil and $0.9503 \mathrm{~g}$ Nd-Fe-B magnets 1/8" x 1/16" disks. These were added to the dissolver as a mixture. One liter of fresh $1 \mathrm{M} \mathrm{H}_{2} \mathrm{SO}_{4}+0.2 \mathrm{M} \mathrm{FeSO}_{4}$ electrolyte was then added to the system and a constant current was applied to the system. The experiment was carried out over 71 hours. Data from the experimental log is shown in Figure 7 where cell current, cell voltage and redox potential are plotted from reading taken during operation. The experiment was operated during work days and shut down each night. The dissolver was rinsed with nanopure water each night to limit corrosion while at rest. This rinse water fed down to the reservoir and acted to replenish water evaporated during operation. As the fresh solution was depleted in dissolved metals, the current was stepped up from $0.5 \mathrm{~A}$ to $1 \mathrm{~A}$, and to a final value of $2 \mathrm{~A}$. The solution evolved from a light yellow to increasing blue to blue-green color as the level of $\mathrm{CuSO}_{4}$ increased. The experiment was carried to the point at which the blue $\mathrm{CuSO}_{4}$ color diminished to a light yellow color from $\mathrm{Fe}^{+3}$. At later stages, the cathode deposit became increasingly dendritic and darker in color. This darkening is attributed to Ag deposition. At the completion of the experiment the remaining metals in the dissolver were weighed. All $\mathrm{Cu}$ and $\mathrm{Nd}-\mathrm{Fe}-\mathrm{B}$ magnets were dissolved. While Ag foil remnants remained, $85 \%$ of $\mathrm{Ag}$ foil weight was lost. The Au and Pd appeared unaffected by the process and no significant weight was lost. The cathode weight increased by $79.28 \mathrm{~g}$. This resulted in a recovery of $97.2 \%$ of $\mathrm{Cu}$ and $\mathrm{Ag}$, which ignores the small amount of $\mathrm{Cu}$ and $\mathrm{Ni}$ from magnet coating or Fe from mediator. After drying the cathode, the loose spongy deposits on the outer surface were knocked free from the cathode 
and reweighed. The cathode has $52.90 \mathrm{~g}$ of compact deposit leaving $26.38 \mathrm{~g}$ of spongy dendritic deposit. Chemical analysis was performed on each deposit as shown in Table 3. Analysis shows that the Ag content increases almost 7 times in the spongy deposit. It was expected that the $\mathrm{Ag}$ would dissolve later in the process due to galvanic coupling described earlier. The spongy deposits could be due to the additional Ag dissolved in solution at later stages of the dissolution altering the deposit structure.

Following the experiment the solution was analyzed for various metals and analysis is provided in Table 4. The solution volume decreased to $790 \mathrm{~mL}$ from evaporation during the long exposure to air draft from operation in a fume hood. Note that the REEs are present as well as $\mathrm{Cu}, \mathrm{Ag}$ and $\mathrm{Ni}$. The Fe added as an oxidizer/mediator was originally $11.17 \mathrm{~g}$ and decreased to $9.18 \mathrm{~g}$. Thus Fe was not significantly reduced by plating at the cathode.

\subsection{Copper-tin chemistry}

The experiments above using the value metals indicated that the electrorecycling process may be viable. Early scoping tests (not presented here) showed that Sn could complicate the dissolution of $\mathrm{Cu}$. Pure Sn and Sn-Ag solder are both readily dissolved in the presence of $\mathrm{Fe}^{+3}$ oxidizer (Table 2). Figure 5 demonstrated a redox reaction between dissolved $\mathrm{Sn}^{+2}$ and $\mathrm{Cu}^{+2}$ is expected to produce $\mathrm{SnO}_{2}$ and $\mathrm{Cu}^{0}$. $\mathrm{SnO}_{2}$ also forms from reaction of $\mathrm{Sn}^{+2}$ and $\mathrm{O}_{2}$. Corrosion experiments presented earlier confirmed this reaction occurs in sulfuric acid based solutions after aging. It is suspected that these films, when formed on $\mathrm{Cu}$, reduce the dissolution rate significantly. Stannate films formed on $\mathrm{Mg}$ alloys have recently been shown to act as a corrosion coating (Hamdy and Butt, 2013). A small scale electrorecycling experiment with only Sn and Cu was performed to determine if dissolved $\mathrm{Sn}$ affected the electrodissolution of $\mathrm{Cu}$. The experiment was operated a short time the first day and left overnight before restarting. During the process Sn shot dissolved readily while the expected blue color due to Cu dissolution did not appear. After the time lag, the Cu shot appeared to have milky coloration which is attributed to formation of $\mathrm{SnO}_{2}$. This could occur either by reaction of $\mathrm{Sn}^{+2}$ and $\mathrm{Cu}$ at the surface or by precipitation of $\mathrm{SnO}_{2}$ dissolved in solution. White precipitate was found away from $\mathrm{Cu}$ as well. Analysis of $\mathrm{Cu}$ shot indicated crystal growth at the surface and EDS confirmed Sn was present (3.3 atomic \%). Note that this EDS value does not adequately represent the true surface composition due to the depth of penetration of the method. The formation of $\mathrm{Sn}$ on copper appears to act as an inhibitor to the electrorecycling process. Thus $\mathrm{SnO}_{2}$ precipitation in the dissolver should be avoided.

From experimental observations it was concluded that the $\mathrm{SnO}_{2}$ reactions are probably slow. To demonstrate this, dissolution experiments were performed by sequentially dissolving Sn foil followed by $\mathrm{Cu}$ foil. Dissolution was performed in $25 \mathrm{~mL}$ of $25 \mathrm{mM} \mathrm{Fe}_{2}\left(\mathrm{SO}_{4}\right)_{3}$ in $1 \mathrm{M} \mathrm{H}_{2} \mathrm{SO}_{4}$. In these experiments, Sn was introduced first and corroded for $\sim 2$ hours where essentially all Fe ${ }^{+3}$ (yellow color had nearly disappeared) was exhausted. The same solution with dissolved $\mathrm{Sn}$ was reconstituted with $\mathrm{Fe}_{2}\left(\mathrm{SO}_{4}\right)_{3}$ and the $\mathrm{Cu}$ foil exposed for 2 hours. In two experiments, the averaged rates were $15.4 \mu \mathrm{m} / \mathrm{hr}$ for $\mathrm{Sn}$ and $4.47 \mu \mathrm{m} / \mathrm{hr}$ for $\mathrm{Cu}$. The value for $\mathrm{Cu}$ was only slightly lower than 
measured without Sn present. The solutions, in capped vials at room temperature, remained clear for over 2 weeks before precipitation was observed. Thus time appears to be a significant factor in this reaction.

The formation of $\mathrm{SnO}_{2}$ is a recognized problem in commercial $\mathrm{Sn}$ plating due to dissolved $\mathrm{O}_{2}$ (Zhang and Abys, 2000). This is particularly an issue when using a non-dissolving anode in the bath where $\mathrm{O}_{2}$ is generated as the anodic reaction. $\mathrm{SnO}_{2}$ can incorporate into plated metal and degrade deposit quality. The plating industry utilizes proprietary antioxidants to prevent $\mathrm{SnO}_{2}$ formation. For the electrorecycling process, the use of anti-oxidants is obviously not possible. The solubility of $\mathrm{Sn}^{+4}$ was shown in Figure 5 as a function of $\mathrm{pH}$. While solubility of $\mathrm{Sn}^{+4}$ increases with acid concentration, unreasonable acid concentrations are required. The obvious method of controlling $\mathrm{SnO}_{2}$ formation will be to speed electroplating (removal) of $\mathrm{Sn}$ at early stages of the electrorecycling process or by using a method to remove $\mathrm{Sn}^{+4}$, perhaps by $\mathrm{pH}$ induced precipitation in a separate process loop followed by filtration. This will be investigated further in subsequent work.

\subsection{Discussion}

The results from the electrorecycling experiment show significant promise. The recovery exceeded $95 \%$ for $\mathrm{Cu}$ and $\mathrm{Ag}$ while leaving $\mathrm{Au}$ and $\mathrm{Pd}$ intact for removal in a second stage. One concern is the formation of dendrites at later stages of the deposition. This might not be a significant problem since there are ways to deal with dendritic deposits and actually might extend the lifetime of the cathode itself.

For commercial application, a membrane divided cell with separate solutions for the anodedissolver and cathode makes more sense. The anode solution would be circulated to the dissolver where the dissolved metal concentration would build. The cathode solution would be saturated with metal ions from a previous dissolution and would capture metals at the cathode. An AEM would maintain separation between the two halves of the cell while allowing anion transport. The solutions would be periodically switched. This should maximize efficiency of both the oxidizer and the cathode. Experiments using this scheme with the trough cell are planned in the future.

How the dissolved REEs in the dissolution solution are separated has not yet been determined. One possibility would be to perform a pH increase to induce precipitation after building up significant amounts in solution (Pietrelli et al., 2002; Bertuol et al., 2009; Lyman and Palmer, 1995). This scheme has been described previously. The disadvantage with this method is the chemical usage to increase $\mathrm{pH}$. If the solution is to be reused, acid may need to be added. Performing electrorecycling experiments at lower acid strength might determine if a higher $\mathrm{pH}$ can be used to limit chemical addition. A second method is to use solvent extraction methods commonly in REE processing (Xie et al., 2014). An alternative being developed is to utilize liquid inorganic membranes to capture REE and later strip (Bhave et al., 2012). As the REEs in mobile electronics would originate primarily from the magnets and LED phosphors, further separation might be needed after extraction as a group. This would involve utilizing a REE separations facility, where they could be inserted into existing primary source separation streams. 


\section{Conclusions}

Mobile electronics offer great potential for recovery of value and critical metals provided effective chemistry is developed. Electrorecycling is a method which utilizes minimal chemical input to dissolve metals and recovery of them on a cathode for further processing. $E$ vs $\mathrm{pH}$ and solubility data was presented for conditions anticipated in the electrorecycling system. Dissolution in oxidizers solutions provided data for rates of dissolution for various metals of interest for recycling. A discussion of recycling schemes was presented before settling on a method using a two-tier approach where less noble metals are dissolved with $\mathrm{Fe}^{+3}$ in sulfate followed by a more aggressive dissolution with $\mathrm{Cl}_{2}$ generated from $\mathrm{HCl}$. An electrorecycling experiment was described where a surrogate metal mix was processed in the electrorecycling system. The initial experiments show great promise with over 95\% recovery of $\mathrm{Cu}+\mathrm{Ag}$ while leaving $\mathrm{Au}$ and $\mathrm{Pd}$. Issues with dissolved $\mathrm{Cu}$ and Sn redox chemistry were described and discussed. REEs from magnet material dissolve into solution readily where either precipitation or extraction methods could be used to capture them. Future directions for developing the electrorecycling process development were discussed in capturing both critical and value metals.

\section{Acknowledgements}

This work is supported by the Critical Materials Institute, an Energy Innovation Hub funded by the U.S. Department of Energy, Office of Energy Efficiency and Renewable Energy, Advanced Manufacturing Office. We thank Byron White for providing analytical services that supported this work.

\section{References}

Alonso, E., Sherman, A.M., Wallington, T.J., Everson, M.P., Field, F.R., Roth, R., Kirchain, R.E., 2012. Evaluating Rare Earth Element Availability: A Case with Revolutionary Demand from Clean Technologies, Environmental Science and Technology 46, 3406-3414.

Anand, T., Mishra, B., Apelian, D., Blanpain, B., 2011. The Case for Recycling of Rare Earth Metals, JOM 63, 8-9.

Anderko, A., Sanders, S.J., Young R.D., 1997. Real-solution stability diagrams: A thermodynamic tool for modeling corrosion in wide temperature and concentration ranges, Corrosion 53, 4353.

Bertuol, D.A., Bernardes, A.M., Tenório, J.A.S., 2009. Spent NiMH Batteries-The Role of Selective Precipitation in the Recovery of Valuable Metals, Journal of Power Sources 193, 914-923.

Beukes, N.T., Badenhorst, J., 2009. Copper Electrowinning: Theoretical and Practical Design, Hydrometallurgy Conference 2009, The Southern African Institute of Mining and Metallurgy, 213-240.

Bhave, R., DeBusk, M.M., DelCul, G.D., Delmau L.A., Narula, C.K., 2012. Supported Liquid Inorganic Membranes for Nuclear Waste Separation, Patent Application US2012/0103900 A1. 
Binnemans, K., Jones, P.T., Blanpain, B., Gerven, T.V., Yang, Y., Walton, A., Buchert, M., 2013.

Recycling of Rare Earths: a Critical Review, Journal of Cleaner Production 51, 1-22.

Brandon, N.P., Kelsall, G.H., Müller, T., Olijve, R., Schmidt, M., Yin, Q., 2001. Metal Recovery from Electronic Scrap by Leaching and Electrowinning, Electrochemical Society Transactions, NJ, Cominellis, C., Doyle, M., Winnick, J. (Eds.), 323-338.

Buchert, M., Manhart, A., Bleher, D., Pingel, D., 2012. Recycling Critical Raw Materials from Waste Electronic Equipment, Oeko-Institut Report for North Rhine-Westphalia State Agency for Nature, Environment and Consumer Protection.

CCS Insight, (2013). Mobile Phone Sales Will Hit 1.86 Billion in 2013 as Strong Smartphone Growth Continues, http://www.ccsinsight.com/press/company-news/1655-mobile-phone-sales-willhit-186-billion-in-2013-as-strong-smartphone-growth-continues

Cheng, C.Y., Kelsall, G.H., Robson, A., Solving a WEEE Problem: Electrochemical Recovery of Metals from End-of-Life Electrical and Electronic Systems, http://www3.imperial.ac.uk/pls/portallive/docs/1/15407696.PDF

Cui J., Zhang, L. (2008). Metallurgical recovery of metals from electronic waste: A review, Journal of Hazardous Materials 158, 228-256.

Diaz, M.A., Kelsall G.H., Welham, N.J., 1993. Electrowinning Coupled to Gold Leaching by Electrogenerated Chlorine I. Au( III) - $\mathrm{Au}(\mathrm{I}) / \mathrm{Au}$ kinetics in Aqueous $\mathrm{Cl} / \mathrm{Cl}^{-}$Electrolytes, Journal of Electroanalytical Chemistry 361, 25-38.

Dini, J.W., 2000, Modern Electroplating, $4^{\text {th }}$ ed., Wiley, New York. Schlesinger, M., Paunovic, M. (Eds.), (Chapter 2).

Gartner, Inc, 2013. Gartner Says Worldwide Mobile Phone Sales Declined 1.7 Percent in 2012, http://www.gartner.com/newsroom/id/2335616

Environmental Protection Agency, 2004. The Life Cycle of a Cell Phone.

http://www.epa.gov/osw/education/pdfs/life-cell.pdf

Gartner, Inc, 2012. Gartner Says Worldwide Media Tablets Sales to Reach 119 Million Units in 2012, http://www.gartner.com/newsroom/id/1980115

Goonan, T.G., 2011. Rare earth elements—End use and recyclability, U.S. Geological Survey Scientific Investigations Report 2011-5094.

Hageluken, C., 2006. Improving Metals Returns and Eco-Efficiency in Electronics Recycling, Proceedings of the 2006 IEEE International Symposium on Electronics and the Environment, San Francisco, CA, 218-223.

Hamdy, A.S., Butt, D.P., 2013. Novel Smart Stannate Based Coatings of Self-Healing Functionality for AZ91D Magnesium Alloy, Electrochimica Acta 97, 296-303.

Herreros, O., Quiroz, R., Viñals, J., 1999. Dissolution Kinetics of Copper, White Metal and Natural Chalcocite in $\mathrm{Cl}_{2} / \mathrm{Cl}$ - Media, Hydrometallurgy 51, 345-357.

Hoenderdaal, S., Espinoza, L.T., Marscheider-Weidemann, F., Graus, W., 2013. Can a Dysprosium Shortage Threaten Green Energy Technologies?, Energy 49, 344-355. 
Huang, K., Guo, J., Xu, Z., 2009. Recycling of Waste Printed Circuit Boards: A Review of Current Technologies and Treatment Status in China, Journal of Hazardous Materials 164, 399-408. Jiricny, V., Roy, A., Evans, J.W., 2002a. Copper Electrowinning using Spouted-Bed Electrodes: Part I. Experiments with Oxygen Evolution or Matte Oxidation at the Anode, Metallurgical and Materials Transactions B 33, 669-676.

Jiricny, V., Roy, A., Evans, J.W., 2002b. Copper Electrowinning using Spouted-Bed Electrodes: Part II. Copper Electrowinning with Ferrous Ion Oxidation as the Anodic Reaction, Metallurgical and Materials Transactions B 33, 677-783.

Kim, E. Y., Kim, M. S., Lee, J.C., Jha, M. K, Yoo .K., Jeong, J., 2008. Effect of Cuprous Ions on Cu Leaching in the Recycling of Waste PCBs, Using Electro-Generated Chlorine in Hydrochloric Acid Solution, Minerals Engineering 21, 121-128.

Kim, E.Y., Kim, M.S., Lee, J.C., Yoo K., Jeong, J., 2010. Leaching Behavior of Copper Using Electro-Generated Chlorine in Hydrochloric Acid Solution, Hydrometallurgy 100, 95-102.

Kim, E.Y., Kim, M.S., Lee, J.C., Jeong, J., Pandey, B. D., 2011. Leaching Kinetics of Copper From Waste Printed Circuit Boards by Electro-Generated Chlorine in $\mathrm{HCl}$ Solution, Hydrometallurgy 107, 124-132.

Lencka, M.M., Nielsen, E., Anderko, A., Riman, R.E., 1997. Hydrothermal synthesis of carbonatefree strontium zirconate: Thermodynamic modeling and experimental verification, Chemistry of Materials 9, 1116-1125.

Lyman J.W., Palmer, G.R., 1995. Hydrometallurgical Treatment of Nickel-Metal Hydride Battery Electrodes, Third International Symposium, Recycling of Metals and Engineered Materials, Mineral and Material Society, 131-144.

Mecucci, A. Scott, K., 2002. Leaching and Electrochemical Recovery of Copper, Lead and Tin from Scrap Printed Circuit Boards, Journal Chemical Technology and Biotechnology 77, 449-457. Masavetas, I., Moutsatsou, A., Nikolalou, E., Spanou, S., Zoikis-Karathanasis, A., Pavlatou, E. A., Spyrellis, N., 2009. Production of Copper Powder from Printed Circuit Boards by Electrodeposition, Global NEST Journal 11, 241-247.

Oishi, T., Koyama, K., Alam, S., Tanaka, M., Lee, J.C., 2007. Recovery of High Purity Copper Cathode from Printed Circuit Boards using Ammoniacal Sulfate or Chloride Solutions, Hydrometallurgy 89, 82-88.

Pietrelli, L., Bellomo, B., Fontana D., Montereali, M.R., 2002. Rare Earths Recovery from NiMH Spent Batteries, Hydrometallurgy 66, 135-139.

Ping, Z., ZeYun, F., Jie, L., Qiang, L., GuangRen, Q., Ming, Z., 2009. Enhancement of Leaching Copper by Electro-Oxidation from Metal Powders of Waste Printed Circuit Board, Journal of Hazardous Materials 166, 746-750.

Pourbaix, M., 1974. Atlas of Electrochemical Equilibria in Aqueous Solutions, 2nd ed., NACE International, Houston, TX. 183-197. 
Stevenson P.C., Nervik, W.E., 1961. The Radiochemistrv of the Rare Earths, Scandium, Yttrium, and Actinium, Lawrence Radiation Laboratory, University of California.

Tanaka, M., Oki, T., Koyama, K., Narita, H., Oishi, T., 2013. Recycling of Rare Earths from Scrap, Handbook on the Physics and Chemistry of Rare Earths 43, 159-211.

Tzanetakis N., Scott, K., 2004. Recycling of Nickel-Metal Hydride Batteries. I: Dissolution and Solvent Extraction of Metals, Journal of Chemical Technology and Biotechnology 79, 919926.

Shao, W., Zangari, G., 2009. Dendritic Growth and Morphology Selection in Copper Electrodeposition from Acidic Sulfate Solutions Containing Chlorides, Journal of Physical Chemistry C 113, 10097-10102.

Schüler, D., Buchert, M., Liu, R., Dittrich, S., Merz, C., 2011. Study on Rare Earths and Their Recycling, Oeko-Institut, Final Report for The Greens/EFA Group in the European Parliament.

Sullivan, D. E., 2006. Recycled Cell Phones-A Treasure Trove of Valuable Metals, United States Geological Survey Fact Sheet 2006-3097.

Tuncuk, A., Stazi, V., Akcil, A., Yazici, E.Y., Deveci, H., 2012. Aqueous Metal Recovery Techniques from E-Scrap: Hydrometallurgy in Recycling, Minerals Engineering 25, 28-37.

U.S. Department of Energy, 2012. Critical Materials Strategy, Report PI-0009.

Veglio, F., Quaresimaa, R., Fornarib, P., Ubaldini, S., 2003, Recovery of Valuable Metals from Electronic and Galvanic Industrial Wastes by Leaching and Electrowinning, Waste Management 23, 245-252.

Veit, H.M., Bernardes, A.M., Ferreira, J.Z., Teńorio, J.A.S., de Fraga Malfatti, C., 2006. Recovery of Copper from Printed Circuit Boards Scraps by Mechanical Processing and Electrometallurgy, Journal of Hazardous Materials B137, 1704-1709.

Wang, P., Anderko, A., Young R.D., 2002. A Speciation-Based Model for Mixed-Solvent Electrolyte Systems, Fluid Phase Equilibria 203, 141-176.

Wang, P., Anderko, A., Springer, R.D., Young, R.D., 2006. Modeling Phase Equilibria and Speciation in Mixed-Solvent Electrolyte Systems II: Liquid-Liquid Equilibria and Properties of Associating Electrolyte Solutions, Journal of Molecular Liquids 125, 37-44.

Wang, P., Anderko, A., Springer, R.D., Kosinski, J.J., Lencka, M.M., 2010a. Modeling Chemical and Phase Equilibria in Geochemical Systems Using a Speciation-Based Model, J. Geochemical Exploration 106, 219-225

Wang, Z., Che, J., Ye, C., 2010b. Application of Ferric Chloride Both as Oxidant and Complexant to Enhance the Dissolution of Metallic Copper, Hydrometallurgy 105, 69-74.

Xie, F., Zhanga, T.A., Dreisinger D., Doyle, F., 2014. A Critical Review on Solvent Extraction of Rare Earths from Aqueous Solutions, Minerals Engineering 56, 10-28.

Zhang, J., Abys, J.A., 2000. Modern Electroplating, $4^{\text {th }}$ ed., Wiley, New York. Schlesinger M., Paunovic, M. (Eds.), (Chapter 6). 


\section{Figure Captions}

Figure 1. Diagram of the electrorecycling system.

Figure 2. E vs. pH diagrams for A) Sn, B) Cu and C) Ag (lines in red) with overlapping diagrams for Fe (lines in black). Conditions are $0.025 \mathrm{M} \mathrm{Fe}_{2}\left(\mathrm{SO}_{4}\right)_{3}$ with $\mathrm{pH}$ adjusted with $\mathrm{H}_{2} \mathrm{SO}_{4}$ and $\mathrm{NaOH}$ at $60^{\circ} \mathrm{C}$ and $1 \mathrm{~atm}$. The passivation and immunity regions are shaded for $\mathrm{Sn}, \mathrm{Cu}$, and $\mathrm{Ag}$ but not for Fe. In diagram (A), amorphous rather than crystalline $\mathrm{SnO}_{2}$ is assumed to reflect its precipitation from solution. The molalities of $\mathrm{Sn}, \mathrm{Cu}$, and $\mathrm{Ag}$ species were assumed to be $10^{-6}$.

Figure 3. $\mathrm{E}$ vs. $\mathrm{pH}$ diagrams for $\mathrm{A}$ ) $\mathrm{Au}$ and $\mathrm{B}$ ) $\mathrm{Pd}$ with a diagram for $\mathrm{Cl}$ overlapping. Conditions are $0.046 \mathrm{M} \mathrm{Cl}_{2}$ with $\mathrm{pH}$ adjusted with $\mathrm{HCl}$ and $\mathrm{NaOH}$ at $60^{\circ} \mathrm{C}$ and $1 \mathrm{~atm}$. The passivation and immunity regions are shaded for $\mathrm{Au}$ and $\mathrm{Pd}$. The molalities of $\mathrm{Au}$ and $\mathrm{Pd}$ species were assumed to be $10^{-6}$. Figure 4. Speciation of $\mathrm{Nd}$ species as a function of $\mathrm{pH}$ at $60^{\circ} \mathrm{C}$ in $1 \mathrm{M} \mathrm{H}_{2} \mathrm{SO}_{4}$. The diagrams have been generated by varying the overall concentration of $\mathrm{Nd}_{2}\left(\mathrm{SO}_{4}\right)_{3}$ and adjusting $\mathrm{pH}$ using $\mathrm{NaOH}$ and $\mathrm{H}_{2} \mathrm{SO}_{4}$.

Figure 5. Speciation as a function of $\mathrm{H}_{2} \mathrm{SO}_{4}$ when $0.2 \mathrm{M} \mathrm{CuSO}_{4}$ and $0.1 \mathrm{M} \mathrm{SnSO}_{4}$ are mixed at $60^{\circ} \mathrm{C}$ and $1 \mathrm{~atm}$.

Figure 6. Proposed flow sheet for a mobile electronic recycling scheme.

Figure 7. Electrorecycling experimental data log values (selected), current $(A), E_{c e l l}$ and redox potential (redox) in (V). 
Table 1. Composition of magnets used in the experiments determined by ICP-MS.

\begin{tabular}{|l|c|c|c|c|}
\hline & $\begin{array}{c}\text { Pr wt } \\
\%\end{array}$ & Nd wt \% & $\begin{array}{c}\text { Gd wt } \\
\%\end{array}$ & Dy wt \% \\
\hline $\begin{array}{l}\text { Ni-Cu-Ni } \\
\text { coated }\end{array}$ & 7.91 & 25.70 & 2.52 & 0.48 \\
\hline Epoxy coated & 7.69 & 24.82 & 1.66 & 2.60 \\
\hline $\begin{array}{l}\text { ER } \\
\text { experiment }\end{array}$ & 5.43 & 18.69 & 0.84 & 0.39 \\
\hline
\end{tabular}

Table 2. Corrosion rates for materials (in $\mu \mathrm{m} / \mathrm{hr}$ ) in various solutions at $60^{\circ} \mathrm{C}$ as determined by gravimetric analysis.

\begin{tabular}{|l|c|c|c|c|c|c|c|}
\hline & $\begin{array}{c}\text { Copper } \\
\text { sulfate }\end{array}$ & $\mathrm{I}_{2}$ & $\begin{array}{c}\text { Ferric } \\
\text { sulfate }\end{array}$ & $\begin{array}{c}\text { Ferric } \\
\text { chloride }\end{array}$ & $\begin{array}{c}\mathrm{O}_{2} \\
\mathrm{H}_{2} \mathrm{SO}_{4}\end{array}$ & $\begin{array}{c}\mathrm{O}_{2} \\
\mathrm{HCl}\end{array}$ & $\mathrm{Cl}_{2}$ \\
\hline $\mathrm{Ni}$ & 1.14 & & 16.43 & 12.91 & 0.51 & 0.99 & 2.01 \\
\hline $\mathrm{Sn}$ & 119.44 & & 14.81 & 17.95 & 0.97 & 3.48 & 9.16 \\
\hline $\mathrm{Cu}$ & 0.60 & & 6.48 & 11.29 & 0.26 & 0.44 & 12.09 \\
\hline $\mathrm{Pd}$ & & & 7.03 & & 0.002 & & \\
\hline Au & & & 0.01 & & & & 4.47 \\
\hline $\begin{array}{l}\text { Coated neo } \\
\text { magnet }\end{array}$ & & 5.5 & 0.0005 & 0.01 & & & 1.01 \\
\hline neo magnet & 1344 & & 1066 & & 1088 & & \\
\hline non-Pb solder & 73.72 & & 23.5 & & 1.61 & 31.84 & \\
\hline
\end{tabular}

Table 3. Composition of cathode in weight $\%$ after digestion and ICP-MS analysis. Cu values are calculated as the remainder.

\begin{tabular}{|l|c|c|c|c|}
\hline & $\mathbf{A g}$ & $\mathbf{F e}$ & $\mathbf{N i}$ & $\mathrm{Cu}$ \\
\hline Compact & 0.56 & 0.02 & 0.0001 & 99.4 \\
\hline Sponge & 3.77 & 0.14 & 0.0003 & 96.1 \\
\hline
\end{tabular}

Table 4. Total amount of dissolved metals (in $\mathrm{g}$ ) in electrorecycling solution ( $790 \mathrm{~mL}$ total) after electrorecycling experiment determined by ICP-MS analysis.

\begin{tabular}{|c|c|c|c|c|c|c|c|}
\hline Pr & Nd & Gd & Dy & Ag & Cu & Fe & Ni \\
\hline 0.0516 & 0.1776 & 0.0080 & 0.0037 & 0.0269 & 0.7647 & 9.1762 & 0.0332 \\
\hline
\end{tabular}


Figure 1

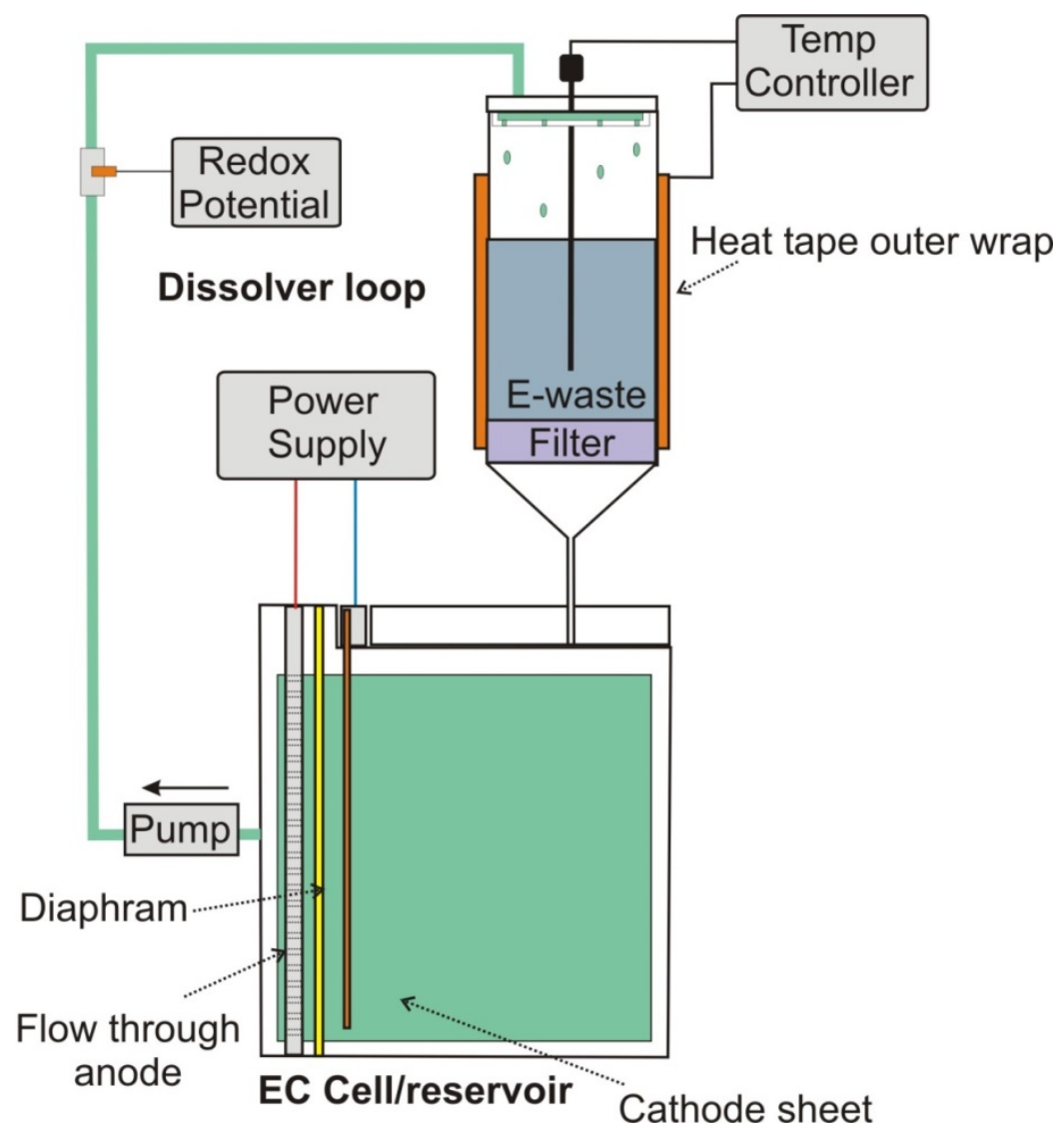


Figure 2
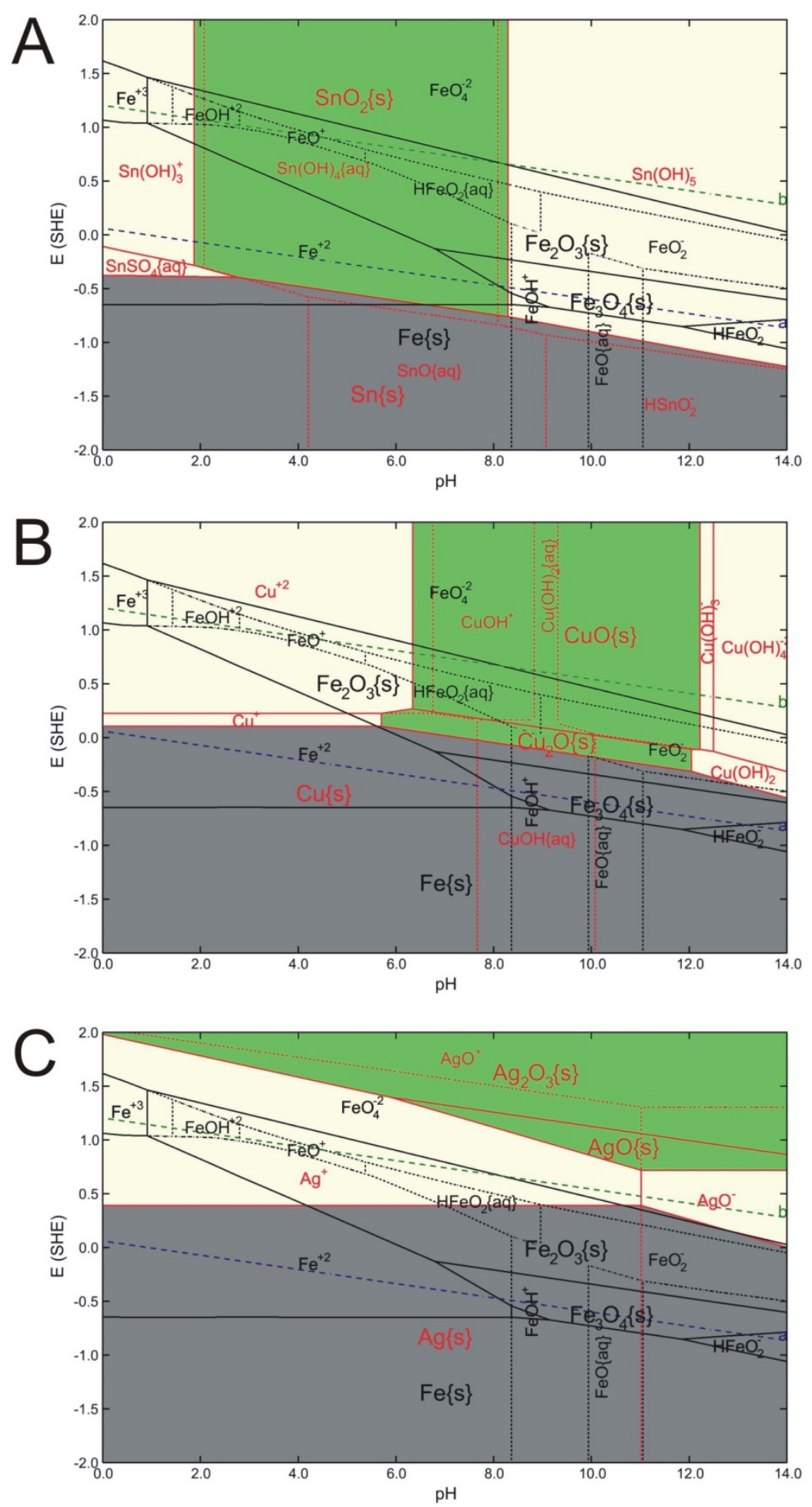
Figure 3
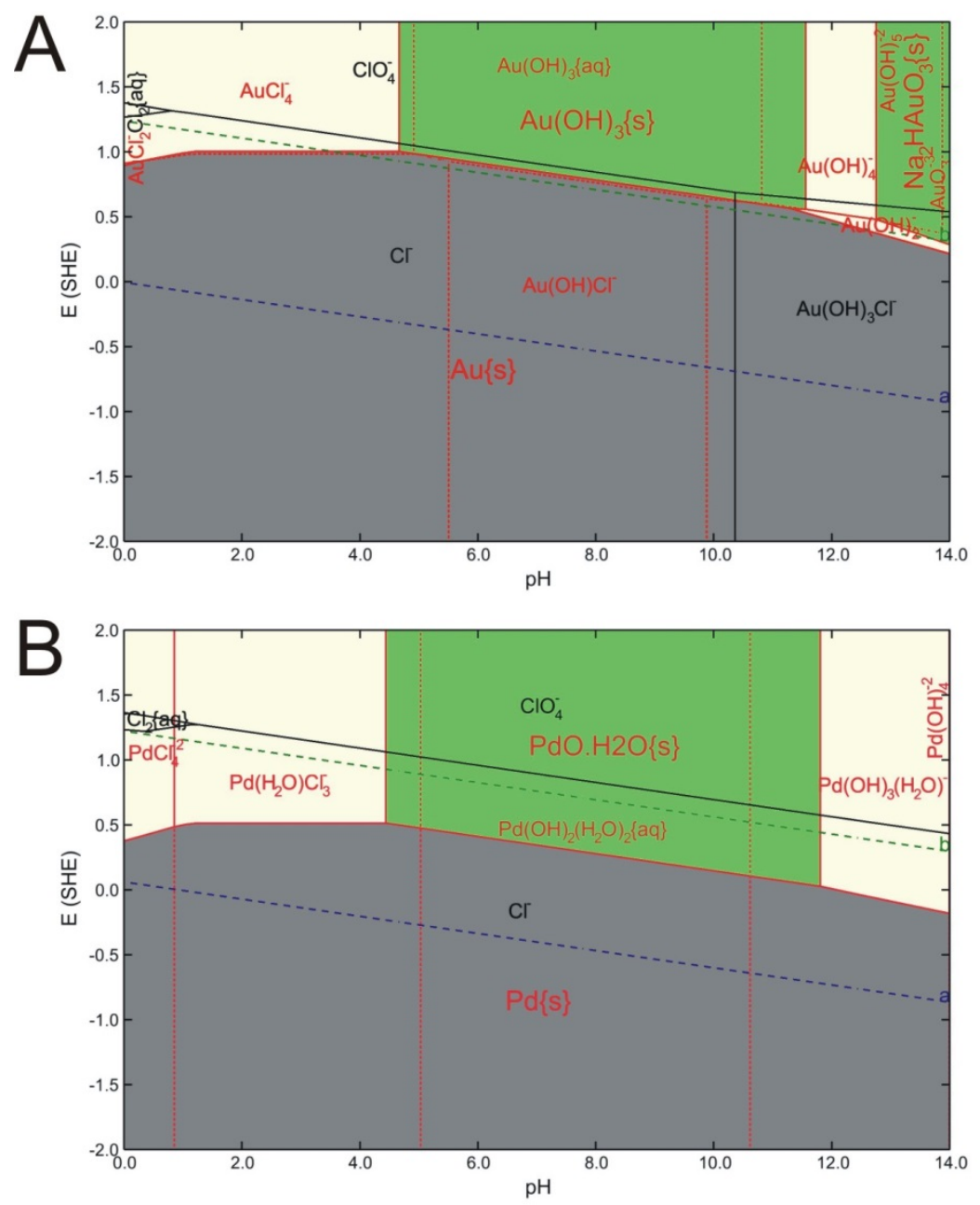
Figure 4

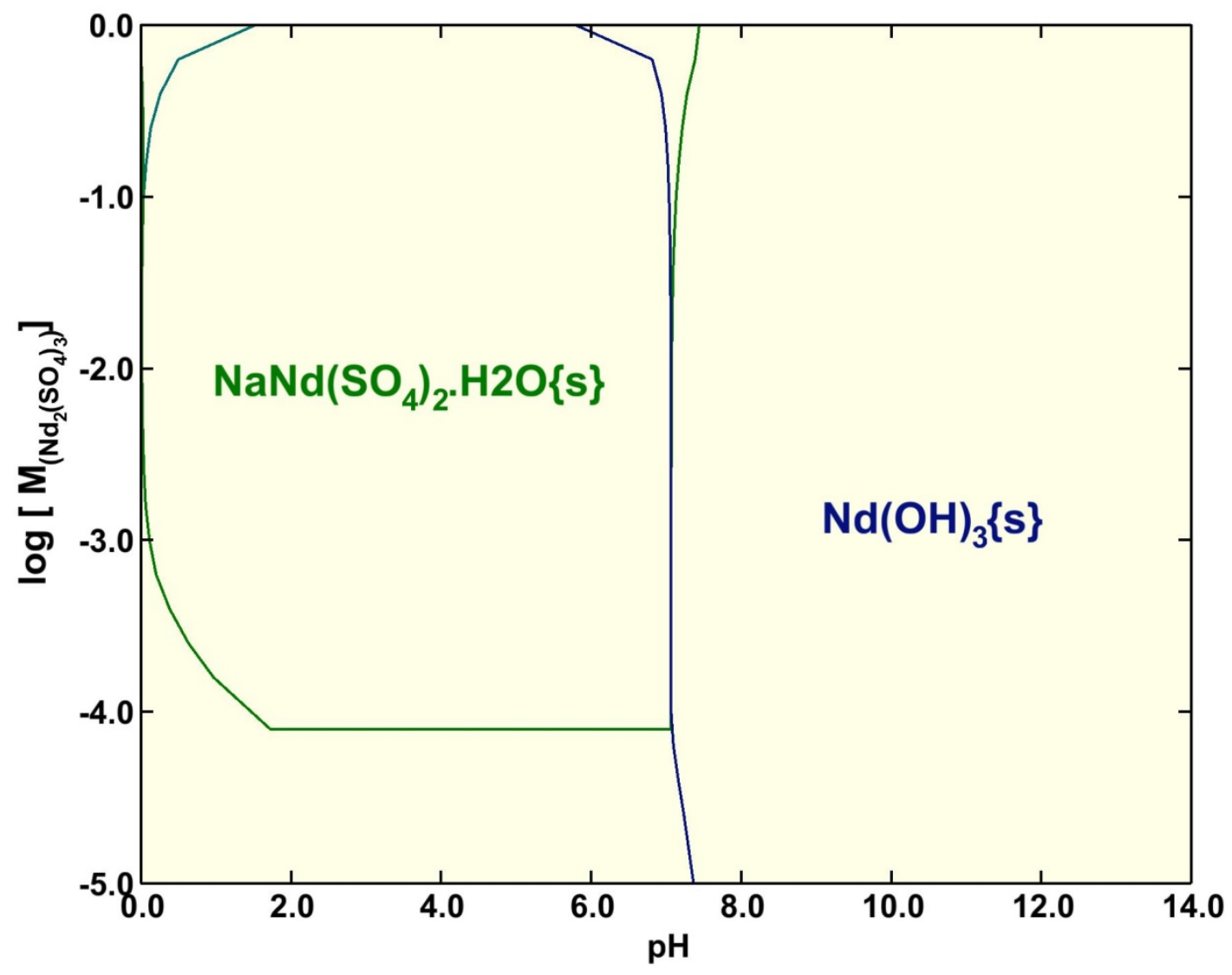


Figure 5

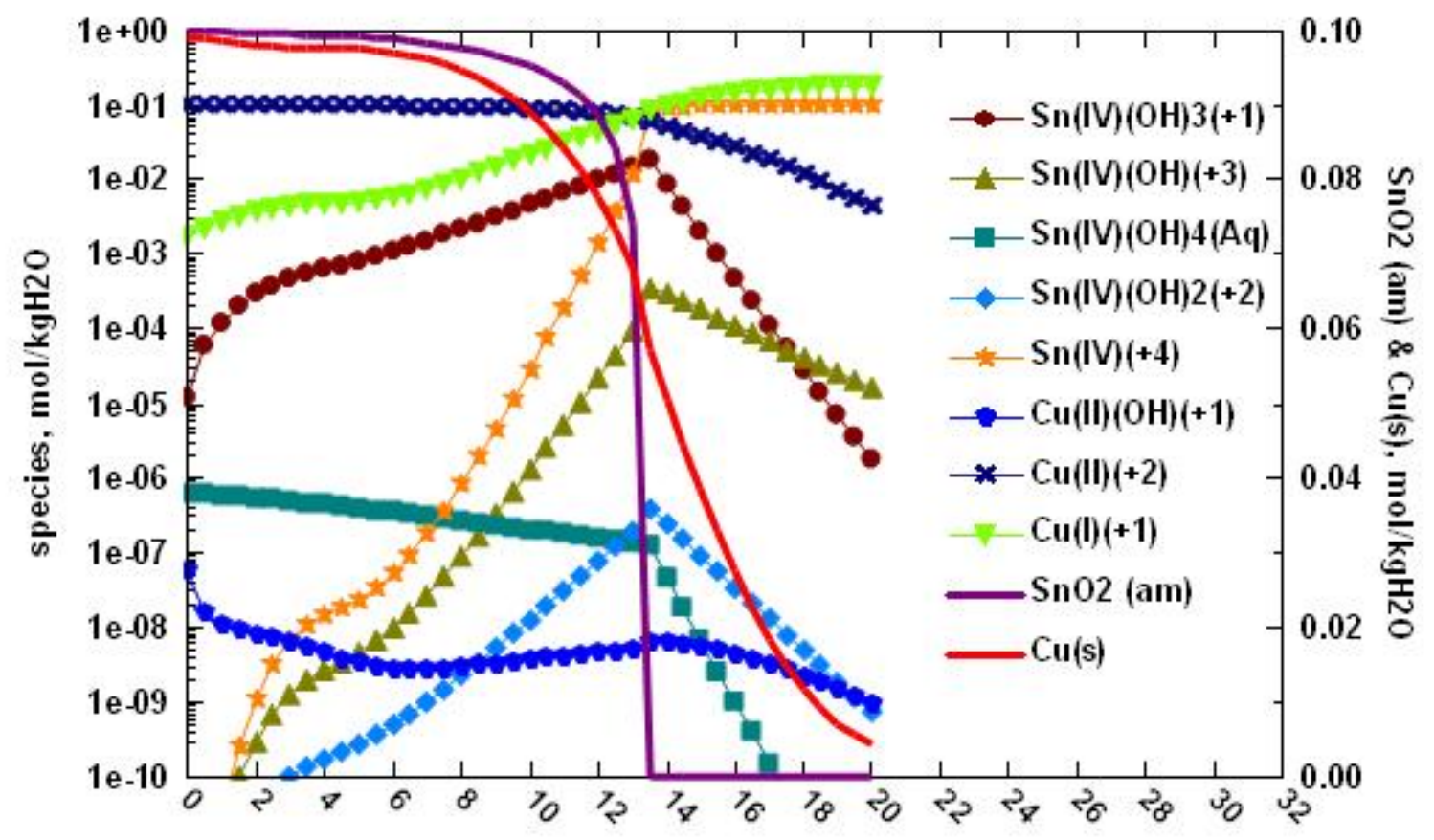

$\mathrm{H} 2 \mathrm{~S} 04, \mathrm{~mol} / \mathrm{kgH} 2 \mathrm{O}$ 
Figure 6

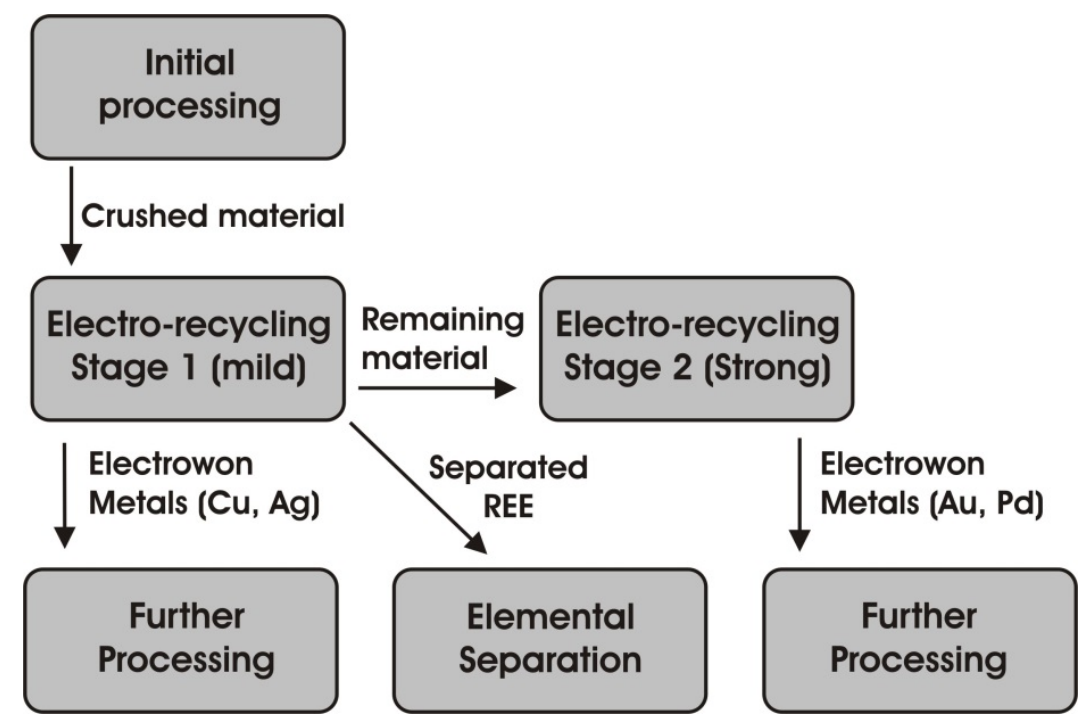


Figure 7

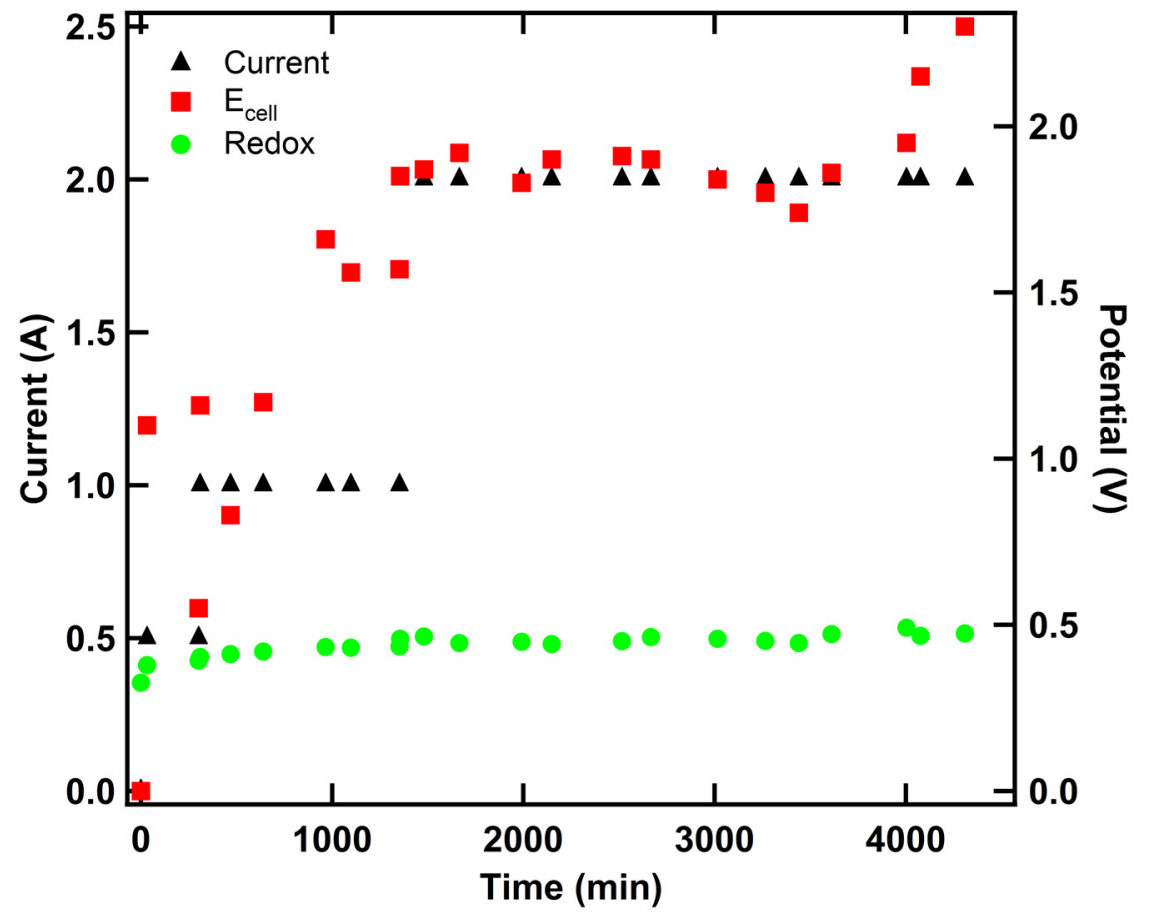

